University of Nebraska - Lincoln

DigitalCommons@University of Nebraska - Lincoln

Eolian sand transport pathways in the southwestern United States: importance of the Colorado River and local sources

Daniel R. Muhs

US Geological Survey, dmuhs@usgs.gov

Richard L. Reynolds

US Geological Survey

Josh Been

US Geological Survey

Gary Skipp

US Geological Survey, gskipp@usgs.gov

Follow this and additional works at: https://digitalcommons.unl.edu/usgsstaffpub

Part of the Earth Sciences Commons

Muhs, Daniel R.; Reynolds, Richard L.; Been, Josh; and Skipp, Gary, "Eolian sand transport pathways in the southwestern United States: importance of the Colorado River and local sources" (2003). USGS Staff -Published Research. 171.

https://digitalcommons.unl.edu/usgsstaffpub/171

This Article is brought to you for free and open access by the US Geological Survey at DigitalCommons@University of Nebraska - Lincoln. It has been accepted for inclusion in USGS Staff -- Published Research by an authorized administrator of DigitalCommons@University of Nebraska - Lincoln. 


\title{
Eolian sand transport pathways in the southwestern United States: importance of the Colorado River and local sources
}

\author{
Daniel R. Muhs*, Richard L. Reynolds, Josh Been, Gary Skipp \\ US Geological Survey, MS 980, Box 25046, Federal Center, Denver, CO 80225, USA
}

\begin{abstract}
Geomorphologists have long recognized that eolian sand transport pathways extend over long distances in desert regions. Along such pathways, sediment transport by wind can surmount topographic obstacles and cross major drainages. Recent studies have suggested that three distinct eolian sand transport pathways exist (or once existed) in the Mojave and Sonoran Desert regions of the southwestern United States. One hypothesized pathway is eolian sand transport from the eastern Mojave Desert of California into western Arizona, near Parker, and would require sand movement across what must have been at least a seasonally dry Colorado River valley. We tested this hypothesis by mineralogical, geochemical and magnetic analyses of eolian sands on both sides of the Colorado River, as well as sediment from the river itself. Results indicate that dunes on opposite sides of the Colorado River are mineralogically distinct: eastern California dunes are feldspar-rich whereas western Arizona dunes are quartz-rich, derived from quartz-rich Colorado River sediments. Because of historic vegetation changes, little new sediment from the Colorado River is presently available to supply the Parker dunes. Based on this study and previous work, the Colorado River is now known to be the source of sand for at least three of the major dune fields of the Sonoran Desert of western Arizona and northern Mexico. On the other hand, locally derived alluvium appears to be a more important source of dune fields in the Mojave Desert of California. Although many geomorphologists have stressed the importance of large fluvial systems in the origin of desert dune fields, few empirical data actually exist to support this theory. The results presented here demonstrate that a major river system in the southwestern United States is a barrier to the migration of some dune fields, but essential to the origin of others.

Published by Elsevier Science Ltd.
\end{abstract}

\section{Introduction}

Dune fields are widespread over the arid and semiarid regions of the southwestern United States and northern Mexico (Fig. 1). Some dune fields are active, such as White Sands in New Mexico, parts of the Gran Desierto and Medanos de Samalyuca in Mexico, parts of the Kelso dunes in California, and most of the Algodones dunes, also in California (Lancaster et al., 1987; Lancaster, 1994, 1995a; Muhs et al., 1995). Other dune fields are partly active but mostly stabilized by vegetation, such as the Parker dunes of western Arizona, the Moenkopi and Chaco dunes on the Colorado Plateau in northeastern Arizona and northwestern New Mexico (Hack, 1941; Wells et al., 1990) and dunes in the southern High Plains of Texas and New Mexico (Muhs and Holliday, 2001). Understanding the history

\footnotetext{
*Corresponding author. Tel.: + 1-303-236-7919; fax: + 1-303-2365349.

E-mail address: dmuhs@usgs.gov (D.R. Muhs).
}

and dynamics of individual dune fields in the southwestern United States is important, because dunes are good indicators of overall moisture balance. The degree of dune activity is highly sensitive to the amount of vegetation cover, and dune geomorphology is often a reliable indicator of past atmospheric circulation regimes. Future climate change, through shifts in overall moisture balance or amount of vegetation cover, could bring about activation of many presently stabilized dune fields in the southwestern United States, particularly in the Colorado Plateau, Southern High Plains, and Basin and Range provinces. The Basin and Range province includes dune fields in both the Mojave and Sonoran Deserts, as well as the Great Basin and Chihuahuan Deserts.

Dunes of the Mojave and Sonoran Desert regions of southeastern California, Arizona, and northern Mexico have received considerable attention for studies of geomorphology, sediment transport, and origins (Lancaster et al., 1987; Tchakerian, 1991; Lancaster, 1994; Muhs et al., 1995; Winspear and Pye, 1995; Zimbelman 


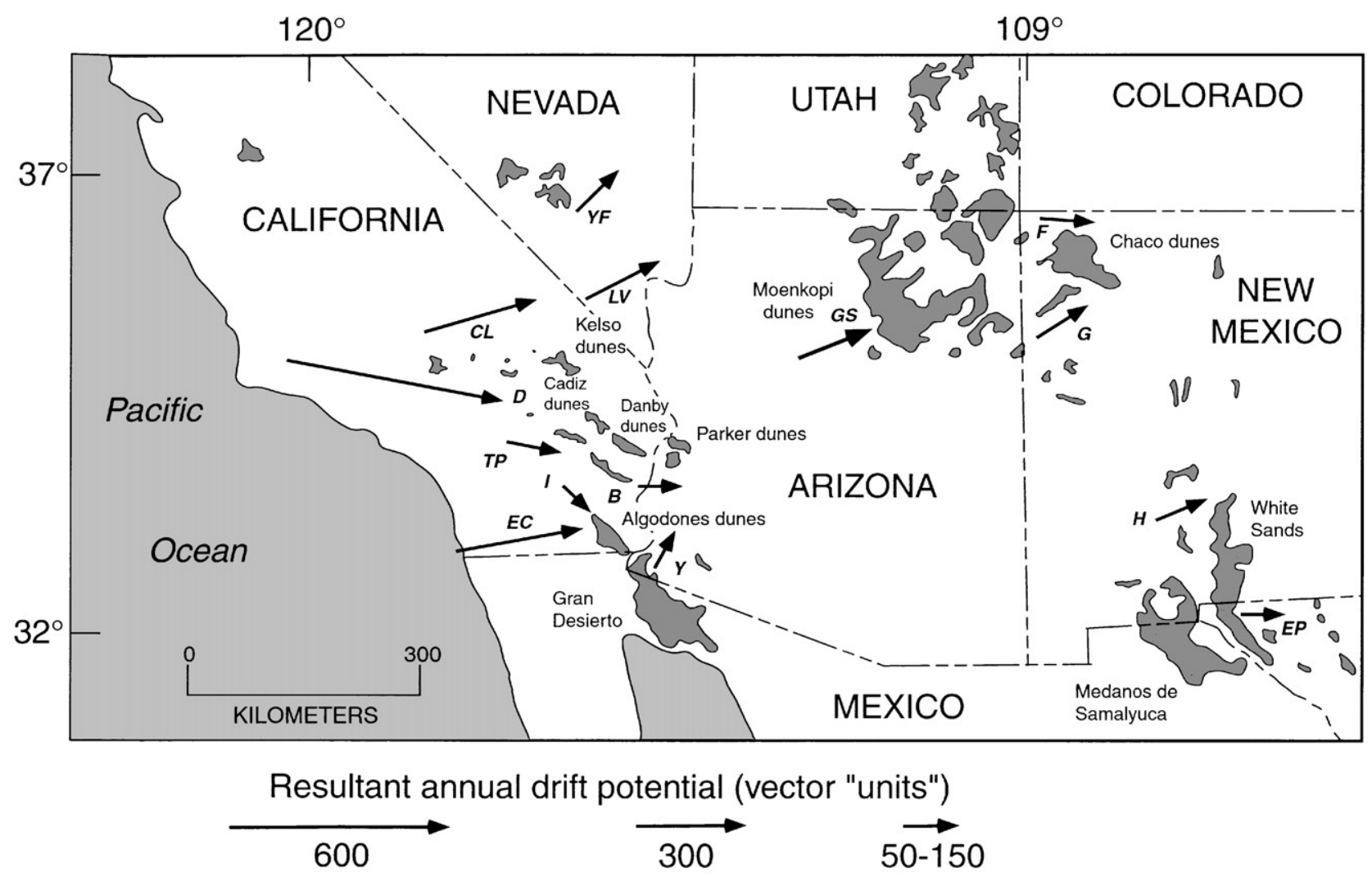

Fig. 1. Map showing the distribution of eolian sand (shaded) in arid and semiarid regions of northern Mexico and the southwestern United States and modern sand transport directions (resultant drift directions and resultant drift potentials, calculated using methods of Fryberger and Dean, 1979). Eolian sand distribution taken from compilation in Muhs and Zárate (2001). Abbreviations for wind direction localities, which approximate the station locations: D, Daggett; CL, China Lake; TP, Twenty-nine Palms; EC, El Centro; I, Indio; B, Blythe; YF, Yucca Flat; LV, Las Vegas; GS, Gold Spring; Y, Yuma; F, Farmington; G, Gallup; H, Holloman Air Force Base; EP, El Paso. Resultant annual drift potentials calculated by the authors except for Gold Spring, which is from Helm and Breed (1999) and Holloman Air Force Base, which is from Fryberger and Dean (1979).

et al., 1995; Lancaster and Tchakerian, 1996). There has also been a considerable amount of effort on dune geochronology (Clarke, 1994; Rendell et al., 1994; Wintle et al., 1994; Clarke et al., 1996; Rendell and Sheffer, 1996; Clarke and Rendell, 1998). Despite the evidence that dunes in the Great Plains record relatively arid periods (Muhs and Maat, 1993; Loope et al., 1995; Muhs and Holliday, 1995; Muhs et al., 1996, 1997a, 1997b) a general concept emerging from studies in the Mojave and Sonoran Deserts is that the degree of activity of many dunes is only indirectly a function of climate. Many of the dune fields in southeastern California seem to be supply-limited or sedimentavailability-limited systems. Therefore, the degree of dune activity may not be related to moisture balance per se, but rather to the effect climate has on supplying new sediment from fluvial or lacustrine sources (Lancaster, 1994; Muhs et al., 1995; Lancaster and Tchakerian, 1996; Clarke and Rendell, 1998; Tchakerian and Lancaster, 2002).

Another concept that has emerged in Mojave Desert dune studies is the presence of distinct sand transport pathways (Fig. 2). Zimbelman et al. (1995) recognized two pathways of sand transport through topographic basins by analysis of dune geomorphology in the field and on Landsat imagery. One of these, called the Clark's Pass sand path, is a northwest-to-southeast trending corridor from the Dale Lake playa to a large sand sheet to the southeast, with continuation southeast to sediment sinks in the Ford-Palen dune field. The other, called the Bristol Trough sand path, is a northwest-to-southeast trending route from Bristol playa to the Cadiz and Danby dune fields, across the Colorado River, and over to the dune fields found near Parker, Arizona. Lancaster and Tchakerian (1996) expanded on the sand transport pathway concept and also discussed paleoclimatic aspects of sediment supply. Clarke and Rendell (1998) recognized both of the sand transport pathways identified by Zimbelman et al. (1995) and added a third, a west-to-east trending route from the Mojave River to Devil's Playground and ultimately to the Kelso dune field. Eolian sand transport pathways that extend over long distances and cross basins, topographic obstacles or major drainages have been recognized by geomorphologists in many of the world's deserts in the past few decades (Wilson, 1973; Fryberger and Ahlbrandt, 1979; Mainguet et al., 1980). 


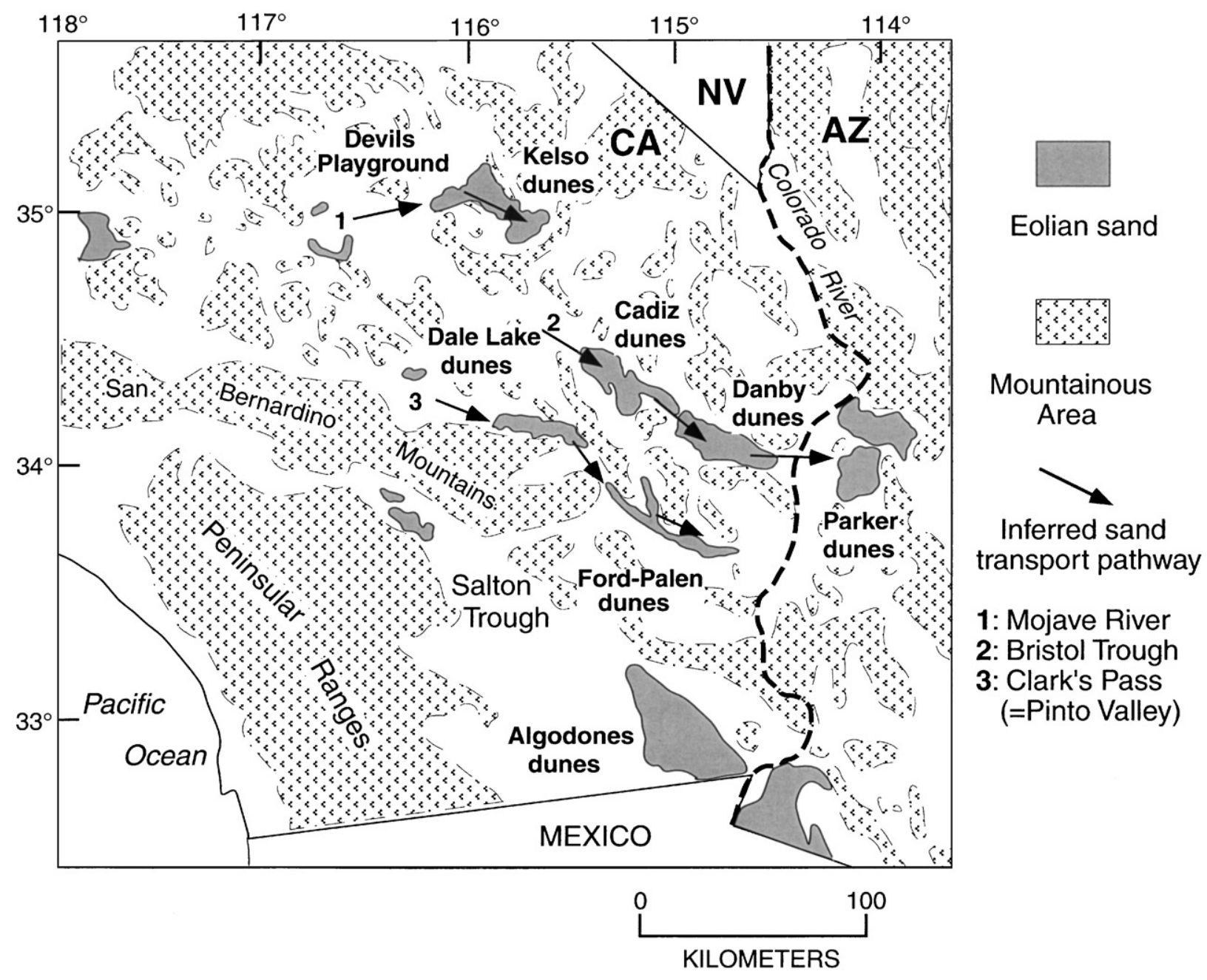

Fig. 2. Inferred sand transport pathways in the eastern Mojave and western Sonoran Deserts, taken from Zimbelman et al. (1995) and Clarke and Rendell (1998).

In this paper, we explore one of these Mojave Desert sand transport pathways using mineralogical, geochemical and magnetic mineralogical data. The Bristol Trough sand path, as conceived by Zimbelman et al. (1995), includes eolian transport of sand from the Cadiz and Danby dune fields of the eastern Mojave Desert across the Colorado River valley to the Parker dune field in western Arizona (Fig. 2). In contrast, however, Metzger et al. (1973, p. 26) suggested that dunes in the Parker area were derived from either modern or older alluvium of the Colorado River. Although the latter investigators presented no geomorphic, mineralogical or geochemical data to support this hypothesis, it is obviously a simpler explanation than the mechanism proposed by Zimbelman et al. (1995).

Transport across the Colorado River valley could be by either of two processes. One mechanism is fluvial transport of sand derived from the Mojave Desert, to the west of the valley, followed by bank deposition, eolian entrainment and transport up the eastern valley side to the Parker area. The other mechanism is exclusively eolian transport across at least a seasonally dry Colorado River valley. This latter hypothesis may seem at first to be highly unlikely, given the fact that the Colorado River is the largest drainage in the southwestern United States. However, numerous studies outside North America have documented infilling of dry river valleys with eolian sand and building of dune dams across major drainages, particularly in Senegal, Mauritania, and Mali (Grove and Warren, 1968), Namibia (Teller and Lancaster, 1986), Botswana, South Africa, and Saudi Arabia (Breed et al., 1979), and Egypt (Haynes, 1980). Infilling of dry valleys by eolian sand has also been well documented on the Southern High Plains of Texas and New Mexico (Holliday, 1995). Recent studies in the Nebraska Sand Hills have shown that dune dams probably developed across small drainages in that region and also across drainages as large as the Platte River system (Loope et al., 1995; Mason et al., 1997; Muhs et al., 2000).

If eolian sand from the eastern Mojave Desert was transported by wind across a dry Colorado River valley, 


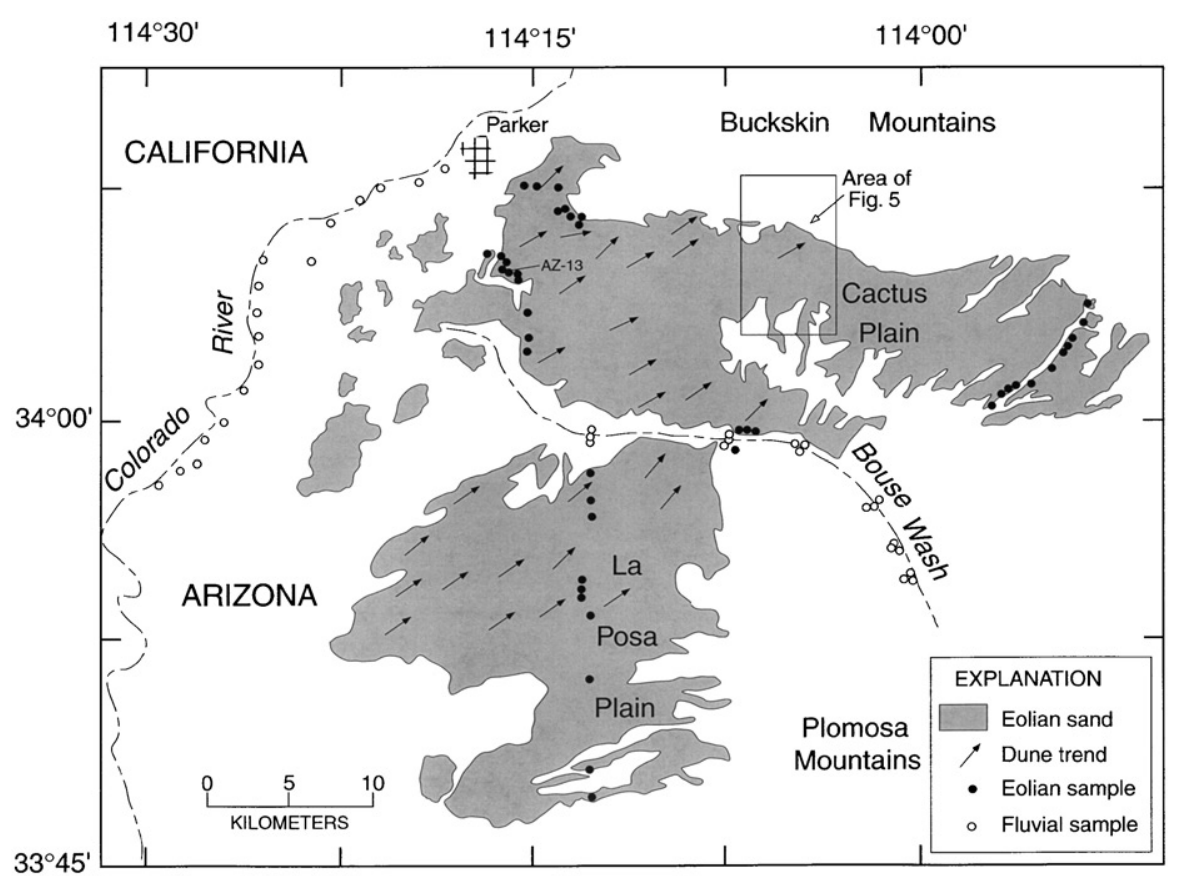

Fig. 3. Map showing distribution of eolian sand in the Parker, Arizona area, dune trends and eolian and fluvial sand sample localities. AZ-13 is a linear dune where detailed analyses were made through a 4 m-thick core (see Figs. 12 and 13). Eolian sand distribution mapped by the authors.

then sand in the Parker dune field should have a composition that is similar to that in dunes at the eastern end of the Bristol Trough sand pathway (i.e, the Cadiz and Danby dune fields). On the other hand, if the Parker dunes originated from Colorado River sediments, they should have a composition that is high in quartz and low in K-feldspar, similar to the Algodones dunes, which have the Colorado River as their ultimate source (Muhs et al., 1995). A third possibility is that the Parker dunes originated from a local alluvial source, such as Bouse Wash, which bisects the dune field (Fig. 3). In this study, mineralogical, geochemical, and magnetic properties are used to identify compositional signatures of these three potential sources and test the opposing hypotheses of Metzger et al. (1973) and Zimbelman et al. (1995).

\section{Methods}

The distribution of eolian sand was mapped using 1:24,000 aerial photographs in the Parker, Arizona area (Fig. 3). We obtained representative surface samples (generally from depths of $\sim 0.3-0.5 \mathrm{~m}$, but below any modern soils) of dune sand (east and west of the Colorado River), Colorado River alluvium, and alluvium from Bouse Wash, a potential local source of dune sand (Fig. 4). After disaggregation and addition of an Na-pyrophosphate dispersant, alluvial samples were wet-sieved to remove gravel, coarse sand, silt and clay. The resultant sediment separate contained grains ran- ging from 500 to $53 \mu \mathrm{m}$, similar to the size range of wellsorted dune sands, and particularly linear dunes (Lancaster, 1995b), which dominate the Parker area.

Both eolian and alluvial samples were characterized for mineralogy, chemical composition and magnetic properties. Semiquantitative abundances of quartz, Kfeldspar, plagioclase, and calcite were determined by measuring X-ray diffraction peak heights, identical to the approach used by Muhs and Holliday (2001). Abundances of $\mathrm{K}, \mathrm{Ca}, \mathrm{Ti}, \mathrm{Fe}, \mathrm{Mn}, \mathrm{Rb}, \mathrm{Sr}, \mathrm{Y}, \mathrm{Zr}, \mathrm{Nb}$, $\mathrm{Ba}, \mathrm{La}$, and $\mathrm{Ce}$ were determined by energy-dispersive $\mathrm{X}$ ray fluorescence, following the methods in Muhs et al. (1995, 1996, 1997a, b). Mineralogical interpretations of these data are based on first principles of geochemistry and element substitution in minerals (Mason and Moore, 1982). Several measurements were used to determine the content of magnetic minerals and the magnetic grain size (or domain state) of magnetite in the sediments. The measurements follow those described by Rosenbaum et al. (1996). The concentration of ironbearing minerals was determined using magnetic susceptibility (MS). MS is dominated by strongly magnetic minerals such as magnetite and related titanomagnetite. The concentration of magnetite and strongly magnetic relatives is determined by isothermal remanent magnetization (IRM, acquired in the laboratory at $0.3 \mathrm{~T}$ ). IRMs acquired at different inductions yield a parameter called "hard" IRM (HIRM) that is a measure of hematite content. Another artificial remanence property, anhysteretic remanent magnetization (ARM), is sensitive to single-domain magnetite. ARM normalized 


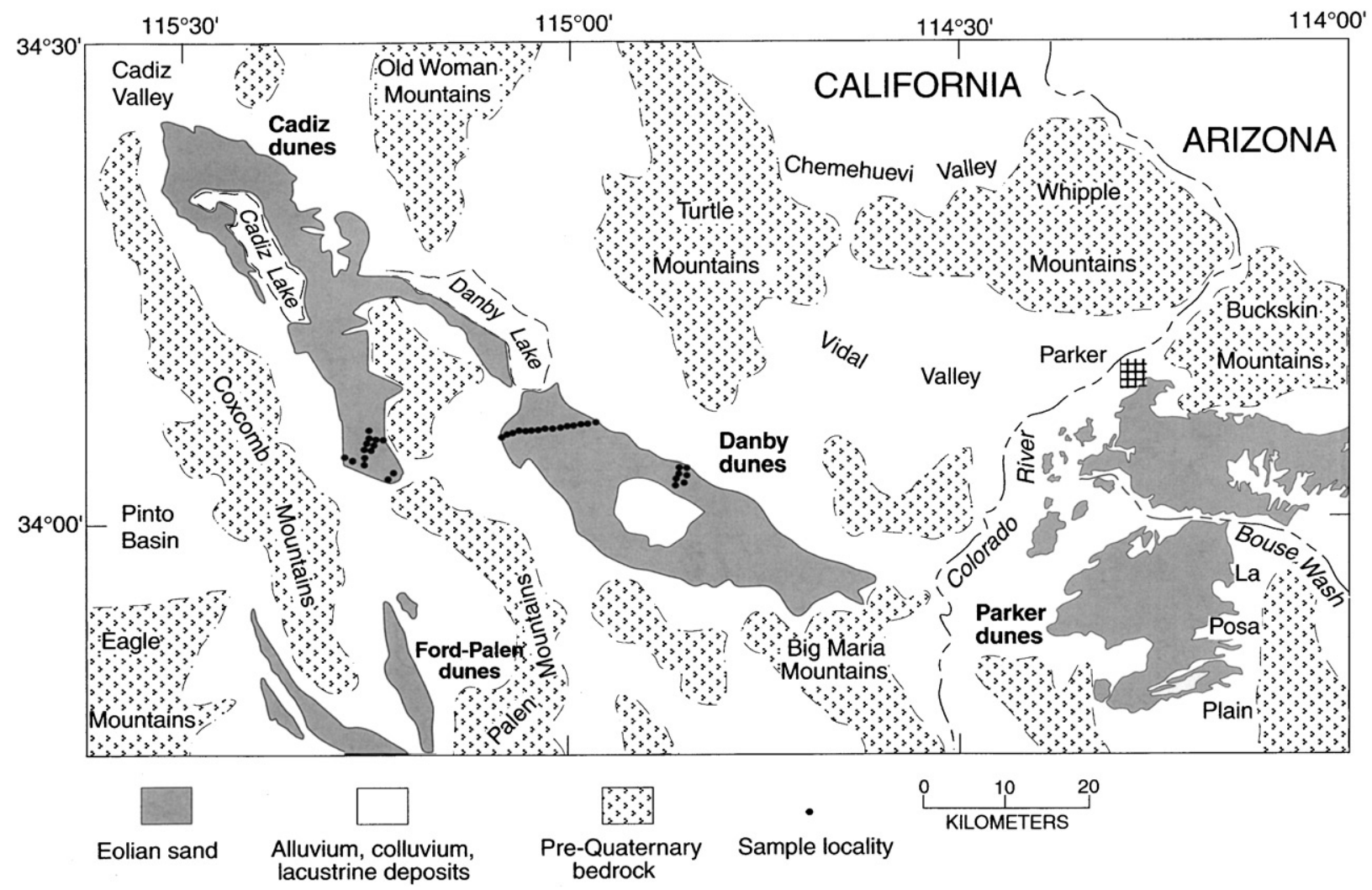

Fig. 4. Map of eolian sand in the eastern Mojave Desert of California and sample localities. Eolian sand west of the Colorado River mapped by Bishop (1963) and Jennings (1967), with minor additional mapping by the authors; eolian sand east of the Colorado River mapped by the authors.

to MS (ARM/MS) yields values that are independent of the concentration of magnetite and reflect the intrinsic property of magnetic grain size (domain state) of magnetite. High ARM/MS values indicate relatively small magnetic grain size (relatively more single-domain magnetite). Similarly, IRM/MS reflects magnetic grain size not specific to the single-domain range; that is, higher values indicate smaller magnetic grain size.

\section{Geomorphology of the Parker dunes}

Most of the eolian bedforms of the Parker dune field are morphologically well expressed linear and parabolic dunes (Fig. 5). Dunes are found on the floodplain of the Colorado River, on a river terrace above the modern floodplain, and on the early Quaternary-Tertiary gravels found above the terrace. Most linear dunes are 1-2 km long, although some are only $200-500 \mathrm{~m}$ long and a few are more than $2 \mathrm{~km}$ long (Fig. 5). Handleveled measurements indicate that dune heights are 3$5 \mathrm{~m}$. In the northeastern part of the study area, dunes are primarily parabolic forms and most are $\sim 100$ $300 \mathrm{~m}$ long. Both types of dunes have well-sorted fine sands, some of which have a slightly pink color, perhaps due to a sparse coating of clay and (or) Fe-oxides.

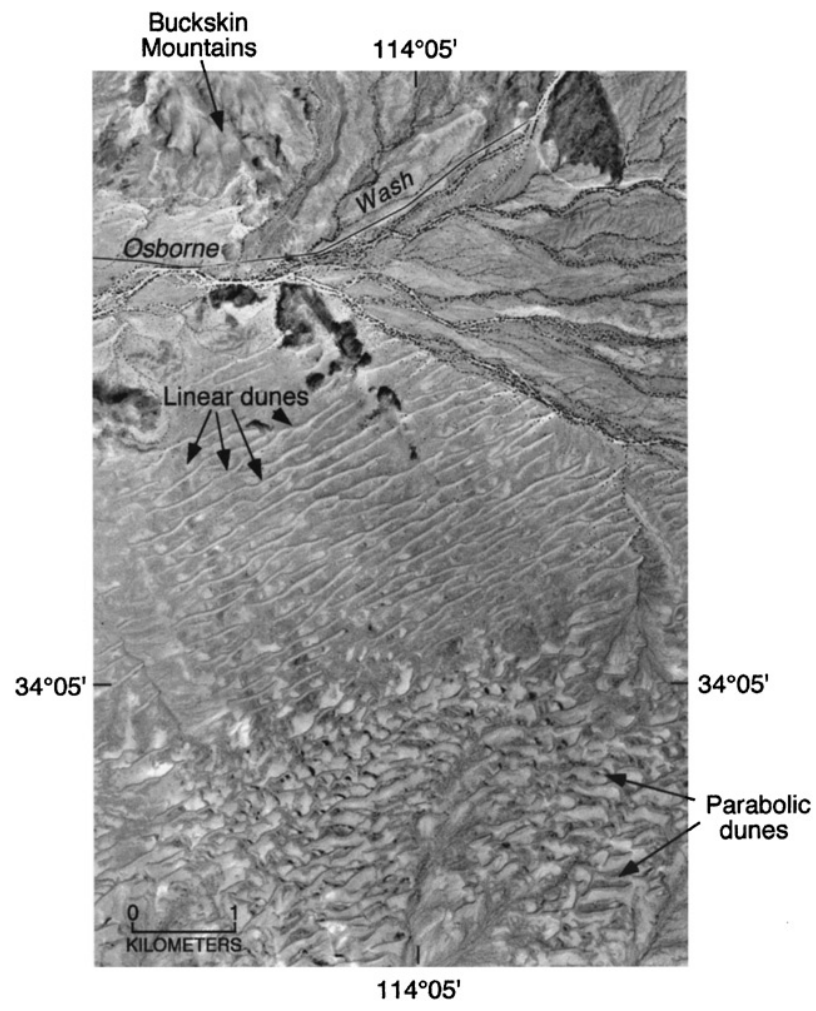

Fig. 5. Aerial photograph showing linear and parabolic dunes in the Parker dune field, Arizona. 
Interdune areas are characterized by thin $(<0.5 \mathrm{~m})$ eolian sheet sands or coppice dunes, underlain by gravel at depths of $1 \mathrm{~m}$ or less.

Dunes are oriented, on average, about $\mathrm{N} 45^{\circ} \mathrm{E}$, indicating dune-forming winds from the southwest. Such a wind direction differs somewhat from the annual resultant drift direction for Blythe, California, the closest locality for which there are sufficient wind data to construct this parameter. At Blythe, resultant drift directions are from west-to-east (Fig. 1). However, southwesterly winds at Blythe are strongest during June, July and August, and suggest that the Parker dunes could have formed under climatic conditions similar to the present, if dune growth took place primarily during summer. Precipitation is lowest in the months of April, May, and June in Parker, and it is possible that this period of very low rainfall, combined with high evapotranspiration in June, July and August, results in a summer-optimum period for dune formation.

The Parker dunes are partially active, with dune crests being the most active. Both linear and parabolic dune crests are typically unvegetated, and ripple marks indicate that sand is actively moving over at least this part of most dunes. Where vegetation does occur on dune crests, it is dominated by mustard, Brassica sp. (possibly Brassica juncea or B. campestris). Dominant interdune plants are Brassica sp., Ambrosia dumosa and creosote (Larrea tridentata). Interdune areas in the easternmost part of the dune field, dominated by parabolic dunes (Fig. 5), have vegetation of the Sonoran type, with ocotillo (Fouquieria splendens) and saguaro cactus (Cereus giganteus), as well as small flowering plants that were especially abundant during the higherrainfall El Nino spring of 1998. During the following, lower-rainfall spring of 1999, flowering plants were far less abundant, and dune crests appeared to be somewhat more active. Given the low rainfall $(114 \mathrm{~mm} / \mathrm{yr})$ and high potential evapotranspiration of the area (nearby Blythe, California is $1270 \mathrm{~mm} / \mathrm{yr}$ ), typical of the Sonoran Desert, it is surprising that these dunes are not more active. The climatic regime has an overall moisture balance little different from that of the nearby Algodones dune field (Fig. 1), which is fully active (Muhs et al., 1995). Using the Lancaster (1988) dune mobility index, Bach (1995) calculated values of 218 and 237 for the nearby cities of Blythe and Needles, California, respectively. These values indicate that the Parker dunes should be fully active.

\section{Mineralogy and geochemistry}

Based on semiquantitative X-ray diffraction studies, the Parker dunes are composed of abundant quartz with much smaller amounts of K-feldspar and plagioclase (Figs. 6 and 7). This finding is consistent with previous geochemical data for two samples that indicated these dunes have $\sim 90 \% \mathrm{SiO}_{2}$ and only $\sim 4.5 \% \mathrm{Al}_{2} \mathrm{O}_{3}$ (Tosdal et al., 1990). In this regard, the Parker dunes have a mineralogy similar to the quartz-rich Algodones dunes of California (Fig. 7), the Nebraska Sand Hills (Muhs et al., 1995, 1997a), and dunes of the Southern High Plains of New Mexico and Texas (Muhs and Holliday, 2001). In contrast, samples collected in the Cadiz and Danby dune fields of the eastern Mojave Desert have much lower quartz and higher amounts of both Kfeldspar and plagioclase (Fig. 6). Most samples of Bouse Wash sediments also have relatively high amounts of Kfeldspar and plagioclase, although a few samples overlap those in the field occupied by samples from the Parker dunes. However, Colorado River sediments are very quartz-dominated (Fig. 7), in agreement with Colorado River data from reaches of this drainage farther south (Muhs et al., 1995).

Geochemical data are consistent with the quartzdominated mineralogy of the Parker dunes and the feldspar-dominated mineralogy of the dunes in the eastern Mojave Desert (Fig. 8). Concentrations of both $\mathrm{K}$ and $\mathrm{Ba}$ (a trace element that follows $\mathrm{K}$ ) are much higher in the Cadiz and Danby dunes and sediments of Bouse Wash than in the Parker dunes. These results are consistent with a higher abundance of $\mathrm{K}$-feldspar in Mojave Desert dunes and Bouse Wash sediments. In
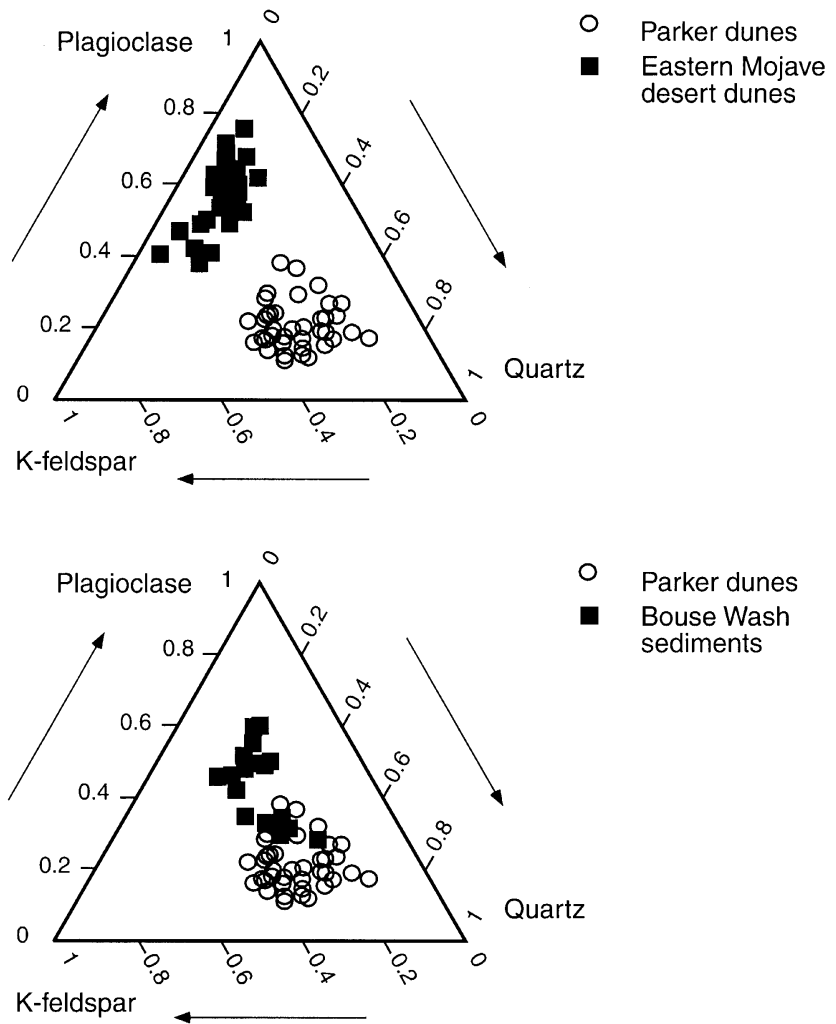

Fig. 6. Ternary diagrams showing relative amounts of quartz, Kfeldspar, and plagioclase in sediments of the Parker dune field, eastern Mojave Desert dune fields in California, and Bouse Wash. 
contrast, Colorado River sediments have lower concentrations of both $\mathrm{K}$ and $\mathrm{Ba}$, and occupy a field that overlaps that of the Parker dunes. Furthermore, the $\mathrm{K} /$ $\mathrm{Ba}$ values of Parker dunes (30-45) and Colorado River sediments (range of 28-43) are, overall, significantly
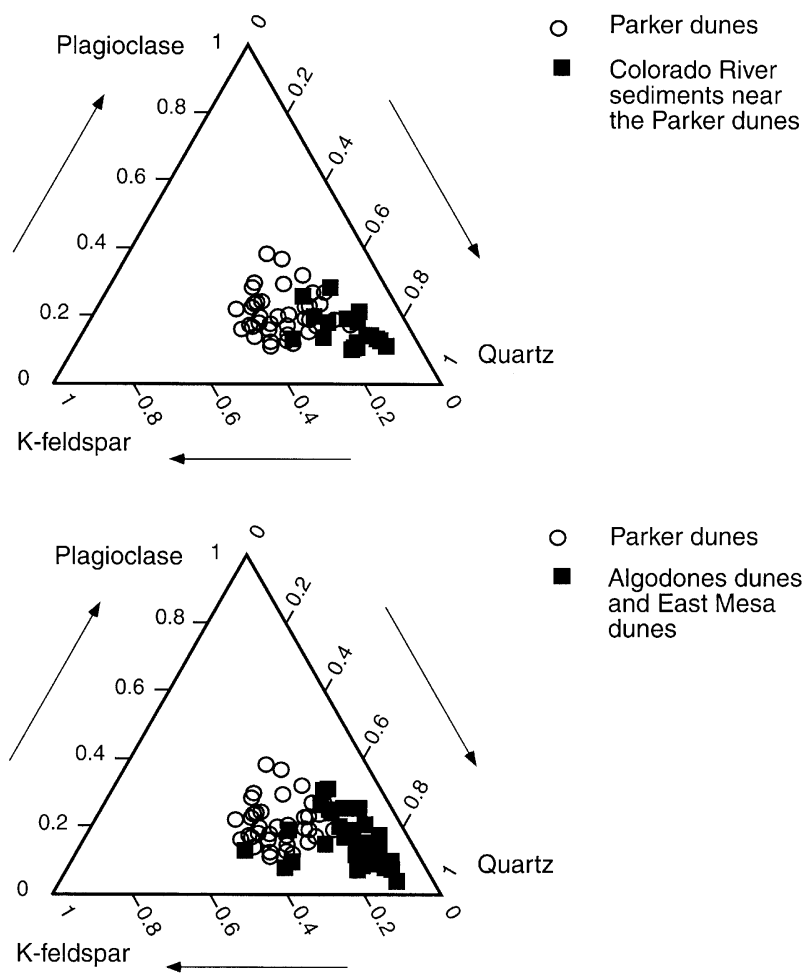

Fig. 7. Ternary diagrams showing relative amounts of quartz, Kfeldspar, and plagioclase in sediments of the Parker dune field, Colorado River sediments, and the Algodones and East Mesa, California dunes. Algodones and East Mesa dune mineralogy data are from Muhs et al. (1995).

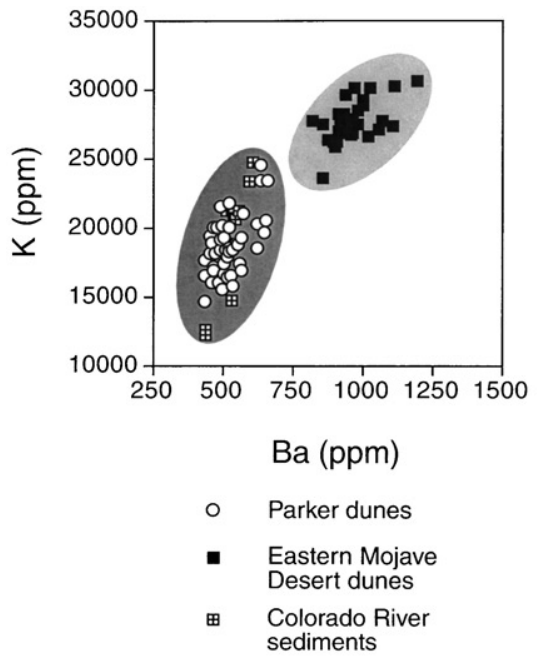

higher than these values in Mojave Desert dunes (range of 25-34) and Bouse Wash sediments (range of 15-32).

Concentrations of $\mathrm{Ca}$ and $\mathrm{Sr}$ (a trace element that substitutes for $\mathrm{Ca}$ ) also show some similarities between Parker dunes and Colorado River sediments and differences between these and Mojave Desert dunes and Bouse Wash sediments (Fig. 9). Abundances of Ca in the Parker dunes are, on average, lower than in Mojave Desert dunes and Bouse Wash sediments. Ca concentrations in Colorado River sediments show a wide range of variability, consistent with mineralogical data that show a similar range of variability in calcite contents. Parker dunes overlap the lower part of this range, but in general have lower $\mathrm{Ca}$ contents than Colorado River sediments. Sr abundances in the Parker dunes are significantly lower than in either Mojave Desert or Bouse Wash sediments, but Parker dunes have Sr concentrations similar to Colorado River sediments. $\mathrm{Ca} / \mathrm{Sr}$ values in the Parker dunes and Colorado River sediments are high and $\mathrm{Ca} / \mathrm{Sr}$ values in Mojave Desert dunes and Bouse Wash sediments are relatively low.

The magnetic properties of the Parker dunes and possible source sediments were compared in an attempt to provide an additional, independent method for assessing sediment provenance. The magnetic approach in this case does not demonstrate as sharp a distinction between the two dune fields as do the mineralogical and geochemical results. Because of uncertainties in how sorting processes in high-energy eolian sand deposits may influence the contents of magnetite and hematite, the concentration parameters (MS and HIRM) are likely to be unreliable discriminators when all sources contain these minerals. The concentration-independent parameters (ARM/MS and IRM/MS) are more reliable discriminators, because these magnetic grain size parameters reflect intrinsic magnetic properties related

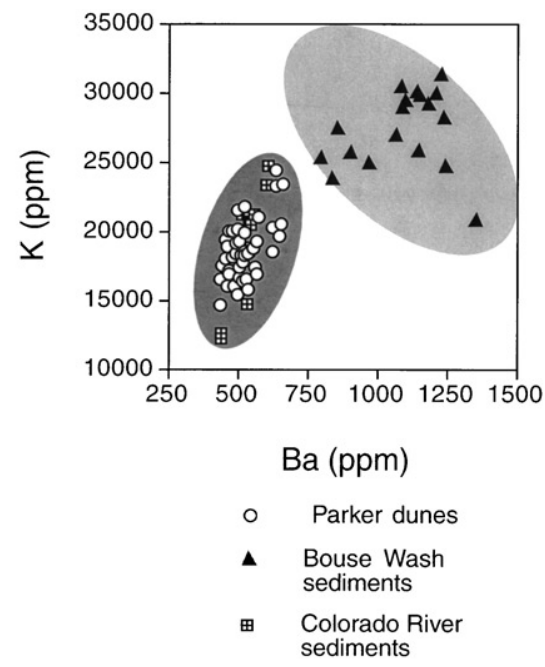

Fig. 8. Plots showing the concentrations of $\mathrm{K}$ and $\mathrm{Ba}$ in sediments of the Parker dune field, eastern Mojave Desert dune fields, Bouse Wash, and the Colorado River. 

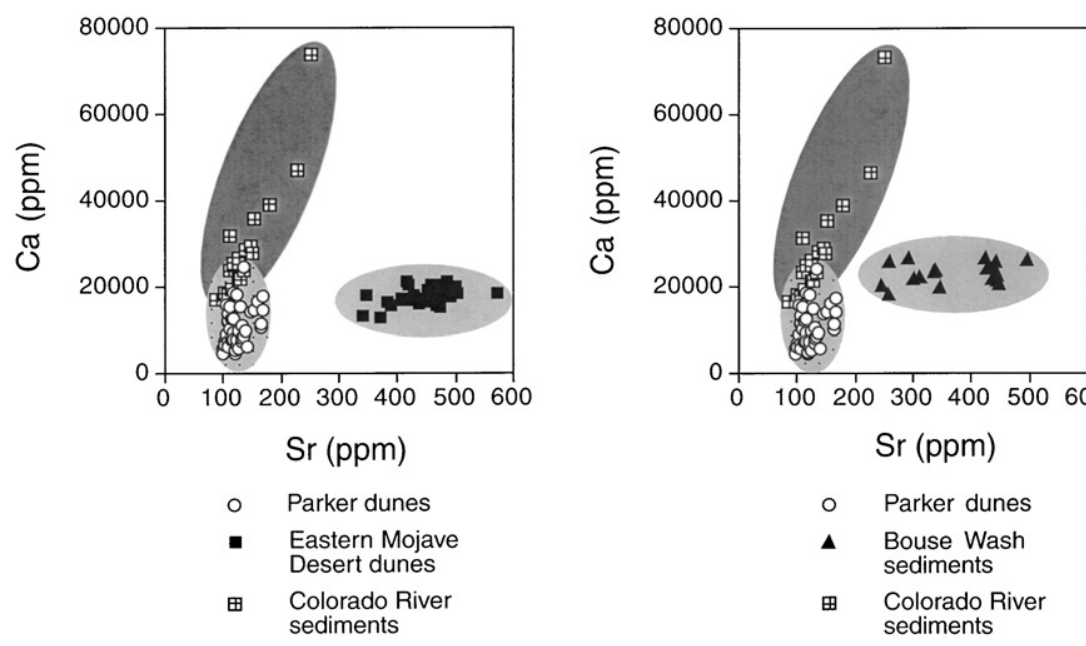

Fig. 9. Plots showing the concentrations of $\mathrm{Ca}$ and $\mathrm{Sr}$ in sediments of the Parker dune field, eastern Mojave Desert dune fields, Bouse Wash, and the Colorado River.
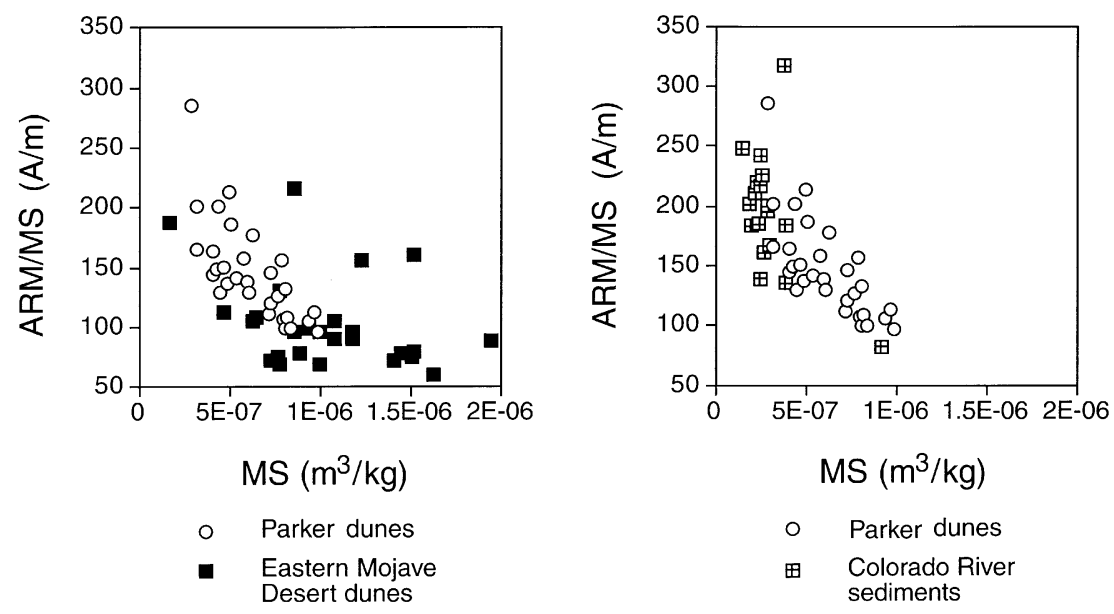

Fig. 10. Magnetic properties of the Parker dunes, dunes from the eastern Mojave Desert and Colorado River sediments. MS, magnetic susceptibility; ARM, anhysteretic remanent magnetization.

strongly to the original compositions and cooling histories of magnetite. Relative to the Mojave dunes, the Parker dunes have higher ARM/MS values (more single-domain magnetite) (Fig. 10). IRM/MS values broadly overlap for both sets of dunes, but the Parker dunes have the highest values (biased toward smaller magnetic grain size) (Fig. 11). These differences are consistent with derivation of some magnetite from basaltic rock at the southern margin of the Colorado Plateau, through which the Colorado River flows. Such rocks are absent in the source regions of the Mojave dunes studied here. The magnetic properties, despite uncertainties, suggest that the Parker dunes have magnetic mineral composition closer to Colorado River sediments than to eastern Mojave Desert dunes.

Analysis of major and trace element concentrations with depth in a single linear dune allows assessment of possible changes in the composition of the Parker dunes over time. A geomorphically well-expressed linear dune (locality AZ-13 on Fig. 3), found a few $\mathrm{km}$ south of Parker, was augered to a depth of $\sim 4 \mathrm{~m}$ and shows three episodes of eolian sand movement (Fig. 12). At the base of the dune, eolian sand hosts a strongly developed stage II calcic horizon (terminology from Gile et al., 1981), with well-developed and very hard carbonate nodules, typically $0.5 \mathrm{~cm}$ in diameter, and as large as $1.5 \mathrm{~cm}$. Concentrations of $\mathrm{Ca}$ are as high as $12 \%$, indicating a $\mathrm{CaCO}_{3}$ content of perhaps as much as $30 \%$, although most parts of this horizon have probable carbonate contents of $\sim 15 \%$. A weaker but discernible carbonate horizon, also with stage II carbonate development, occurs above the older calcic horizon, whereas clean, well-sorted eolian sand with no evidence of pedogenesis comprises the $275 \mathrm{~cm}$ of sediment above the younger calcic horizon. Calcite/quartz values (based on X-ray diffractogram peak heights), Ca content, and $\mathrm{Sr}$ content all show higher values in the two calcic horizons (Fig. 12). Based on chronologies developed in 

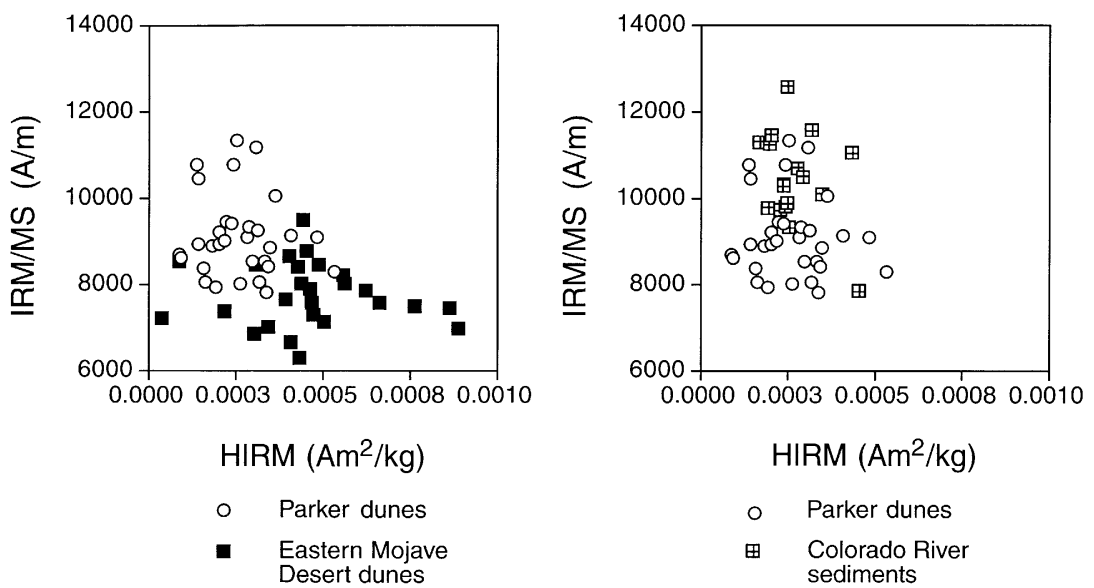

Fig. 11. Magnetic properties of the Parker dunes, dunes from the eastern Mojave Desert and Colorado River sediments. MS, magnetic susceptibility; IRM, isothermal remanent magnetization; HIRM, "hard" IRM (a measure of hematite content).

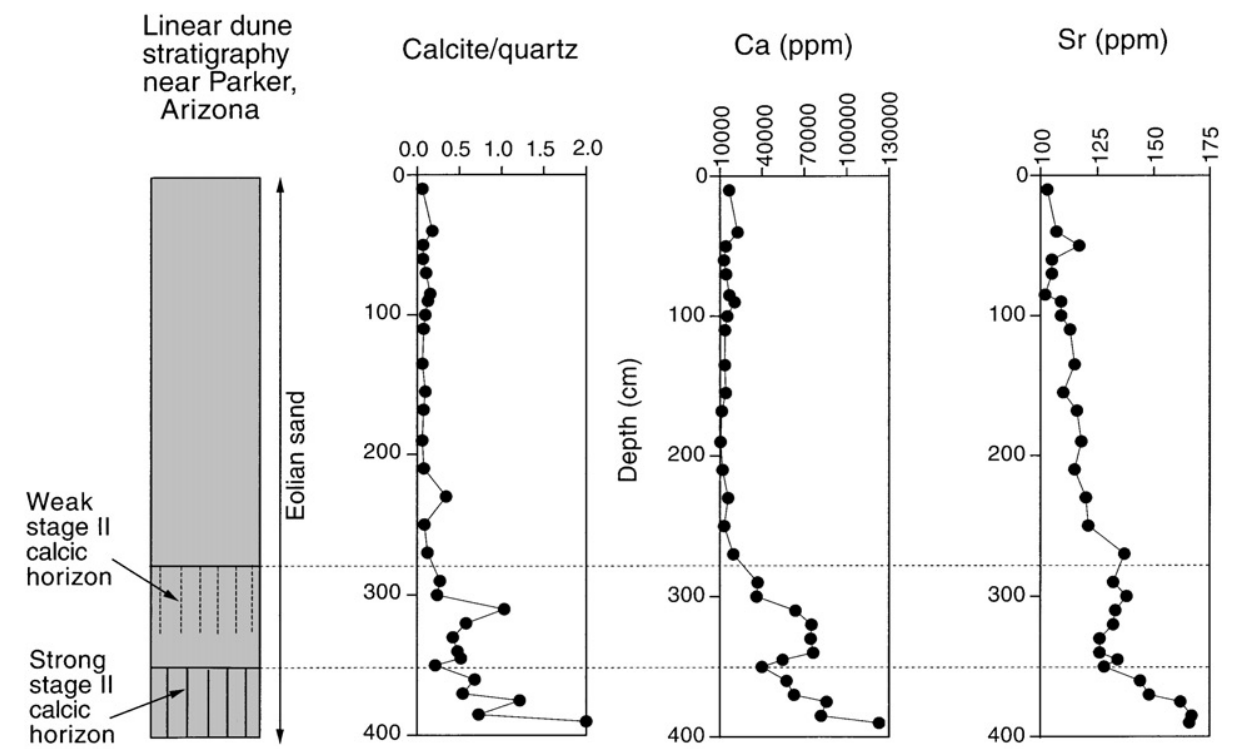

Fig. 12. Stratigraphy of a linear dune (AZ-13, Fig. 3) near Parker, Arizona and concentrations of Ca and Sr as a function of depth.

the Las Cruces, New Mexico area, stage II calcic horizons can take $8000-15000$ yr to form (Gile et al., 1981). However, in the Parker area, precipitation is much lower than around Las Cruces, and calcic horizons may take longer to form. The closest locality where detailed studies of carbonate horizon development have been conducted is Vidal Junction, California, $\sim 30 \mathrm{~km}$ west of Parker. Machette (1985) estimates that stage II calcic horizons at Vidal Junction take somewhat longer to form than in the Las Cruces area; therefore, the calcic horizons at Parker could represent up to 15,000 or more years of dune stability and pedogenesis. New stratigraphic data and luminescence ages of eolian sands in the Danby dunes of eastern California (Fig. 4) show a similar history. In addition to modern, active sands, there are at least two earlier phases of eolian activity separated by periods of soil formation with calcic horizons; luminescence ages suggest periods of eolian activity prior to $\sim 22,000-20,000 \mathrm{yr}$ ago and between 15,000 and 9,000 yr ago (Rendell and Sheffer, 1996).

Depth functions of K-feldspar/quartz, K content, and $\mathrm{Ba}$ content all suggest that the composition of the Parker dunes has changed little over the past three cycles of eolian sand deposition (Fig. 13). Although there are small fluctuations in K-feldspar/quartz and $\mathrm{K}$ content, most values are within the range found in Colorado River sediments and are not as high as the main range of values for Bouse Wash sediments or dunes in the eastern Mojave Desert. Concentrations of Ba change very little as a function of depth and all are within the range of Colorado River sediments; none are within the ranges of eastern Mojave Desert dunes and Bouse Wash sediments. $\mathrm{K} / \mathrm{Ba}$ values within this dune range from 29 to 

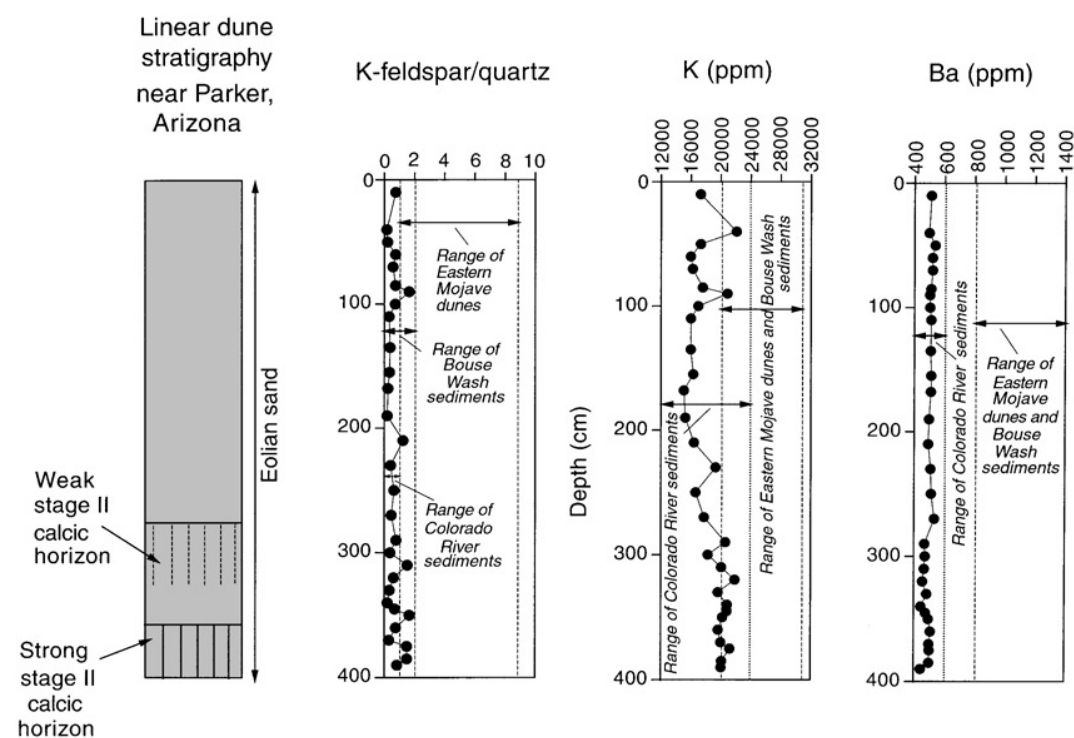

Fig. 13. Stratigraphy of a linear dune near Parker, Arizona and concentrations of $\mathrm{K}$ and $\mathrm{Ba}$ as a function of depth. Ranges of $\mathrm{K}$ and $\mathrm{Ba}$ in other sediments (taken from data in Fig. 8) are shown for comparison.

48, which is not significantly different from the overall range for the Parker dune field (30-45) and is similar to the range for Colorado River sediments (28-43).

\section{Discussion}

On the basis of the combined evidence from mineralogy, geochemistry, and sediment magnetic properties, the Parker dunes have a composition much closer to Colorado River sediments than to either eastern Mojave Desert dunes or sediments of Bouse Wash. As with Colorado River sediments, the Parker dunes are high in quartz and depleted in K-feldspar, which is shown by both the X-ray diffraction data and $\mathrm{K}$ and Ba contents. The Parker dunes also appear to be much lower in plagioclase content than either the eastern Mojave Desert dunes or Bouse Wash sediments. Concentrations of $\mathrm{Sr}$ and $\mathrm{Ca} / \mathrm{Sr}$ values in the Parker dunes are similar to those in Colorado River sediments and differ from either eastern Mojave Desert dunes or Bouse Wash sediments. The relatively low magnetic susceptibility values of the Parker dunes and Colorado River sediments are consistent with their high content of quartz, which may dilute the overall magnetic mineral content. Similarly, the Parker dunes and Colorado River sediments have lower hematite contents than dunes in the eastern Mojave Desert. Differences are also apparent in concentration-independent magnetic grain-size parameters, strongly suggesting different sources for magnetite. These differences are consistent with derivation of some magnetite in the Parker dunes from finegrained, basic volcanic rocks, such as occur not far upstream along the Colorado River drainage. Based on stratigraphic, mineralogical, and geochemical evidence, the composition of sand in the Parker dunes has not changed significantly over at least three cycles of eolian deposition, suggesting an unchanging source during late Pleistocene and Holocene time.

It is possible that the Parker dunes originated from a relatively feldspar-rich, quartz-poor source and are depleted in feldspar as a result of eolian processes themselves. Work by Dutta et al. (1993) has shown, on the basis of both theoretical calculations and laboratory experiments, that ballistic impacts under strong (> $10 \mathrm{~m} / \mathrm{s}$ ) winds can mechanically break sand-sized Kfeldspar grains down to silt sizes. Silt-sized K-feldspars can then be removed from the dune field by suspension in wind, leaving a quartz-rich dune field. This mechanism can explain the quartz-rich composition of dune sands in some of the world's largest sand seas. For example, a comparison of the composition of dunes in the $50,000 \mathrm{~km}^{2}$ Nebraska Sand Hills with all possible source sediments shows that the eolian sediments are depleted in $\mathrm{K}, \mathrm{Rb}$, and $\mathrm{Ba}$, likely the result of ballistic impacts causing destruction of K-feldspar grains (Muhs et al., 1997a). If such a mechanism has been operating on the Parker dunes, then it is possible that they could have originated from either eastern Mojave Desert dunes or locally from Bouse Wash.

Although a ballistic impact origin for the quartz-rich Parker dunes is plausible, two lines of evidence argue against it. First, ballistic impacts do not explain the different ARM/MS values in the Parker dunes and eastern Mojave Desert dunes. These values are intrinsic to sand-sized particles and are not a result of physical modification. Second, wind strengths in Nebraska are much higher than those in the Parker, Arizona area. 
Annual drift potentials in the Nebraska Sand Hills range from $\sim 300$ to more than 900 vector "units" (terminology of Fryberger and Dean, 1979), whereas Blythe, California has a drift potential of only about 200 vector "units." Furthermore, the distances of transport from either Bouse Wash or the eastern Mojave Desert to the Parker dunes are not great (Figs. 2, 3). If the Parker dunes owed their quartz-rich composition to ballistic impacts from a feldspar-rich source, it seems likely that some transitional compositions would be expected along the transport pathway. Transitional compositions could be expressed either as somewhat more feldspar-rich dunes immediately north of Bouse Wash, or more quartz-rich dunes in the easternmost parts of the Mojave Desert dunes in California.

On the other hand, eolian processes may explain other compositional differences between the Parker dunes and possible source sediments. Although ballistic impacts under strong winds may be required to reduce sand-sized K-feldspar grains to silt sizes, eolian abrasion of much softer minerals, such as calcite and dolomite, can reduce sand-sized grains to silt-sized grains. Theoretical considerations (Pye and Tsoar, 1990 , p. 82), experimental studies (Marsland and Woodruff, 1937; Kuenen, 1960), and field studies (Muhs et al., 1997b; Arbogast and Muhs, 2000) all suggest that eolian abrasion of carbonate minerals may be an important process in many dune fields. If so, then it is possible that the generally lower concentration of $\mathrm{Ca}$ in the Parker dunes compared to both Colorado River and Bouse Wash sediments is due to eolian abrasion of soft carbonate minerals during transport.

The simplest interpretation of the mineralogical and geochemical data is that the Parker dunes originated as quartz-rich, K-feldspar-depleted dunes, derived from sediments of the Colorado River. In this scenario, the mineralogical maturity of the dunes is inherited from the parent sediment, and is not the result of a long history of ballistic impacts from extended periods of eolian activity. Much of the sediment supply to the Colorado River comes from the easily weatherable Mesozoic sedimentary rocks of the Colorado Plateau, which are themselves mineralogically mature sandstones. Howard (1947) reported that sediment contributed by the Little Colorado River in the Colorado Plateau could be one of the major sources of suspended sediment (which is $\geqslant 60 \%$ sand-sized particles) in the lower Colorado River. Billingsley (1987) showed that Triassic and Jurassic sandstones of the Colorado Plateau, which are drained by the Little Colorado River upstream of its confluence with the Colorado River, have quartz contents of $60-100 \%$. We conclude from these observations that much of the sand in the lower Colorado River, and hence the Parker dunes, is quartz-dominated because of inputs from the Colorado Plateau. Quartz is also the dominant constituent in Colorado River alluvium in downstream reaches, such as that studied by Muhs et al. (1995) near Yuma, Arizona. The origin of the Parker dunes, therefore, does not require transport of eolian sand across a dry Colorado River valley, as envisaged by Zimbelman et al. (1995). Similar conclusions were reached by Zimbelman and Williams (2002) and Pease and Tchakerian (2002) in parallel studies of the Parker dunes, eastern Mojave dunes and Colorado River sediments. Zimbelman and Williams (2002) report high quartz and $\mathrm{SiO}_{2}$ contents in the Parker dunes and Colorado River sediments and lower quartz and $\mathrm{SiO}_{2}$ contents in eastern Mojave dunes. Based on major element chemistry and mineralogy, they also conclude that the Parker dunes were derived from Colorado River sediments and eastern Mojave dunes were derived from local sources.

If our interpretation of the origin of the Parker dunes is correct, it adds to the growing body of evidence that the Colorado River is an important source of sediment for some of the major dune fields of the southwestern United States and northwestern Mexico (Fig. 1). Blount and Lancaster (1990) and Lancaster (1995a) showed that the Colorado River was one of the main sources of eolian sand in the Gran Desierto sand sea of northwestern Mexico. Muhs et al. (1995) and Winspear and Pye (1995) showed that the Colorado River was the ultimate source of sand in the Algodones dunes and East Mesa dunes of the Salton Trough in southern California.

Based on the findings reported here, we hypothesize that the sources of sand in other dune fields of the southwestern United States can be identified as either the Colorado River or local alluvium derived from nearby granitic mountain ranges. For example, eolian sand sheets and coppice dunes in the Yuma Desert occur to the east of the Colorado River in Arizona and are essentially the northernmost part of the Gran Desierto sand sea (Figs. 1 and 15). Breed (1999) hypothesized that dunes and sand sheets in the Yuma Desert were derived from alluvium eroded from the Gila Mountains to the east. However, this origin would require easterly sand-moving winds, which are rare or non-existent in the Yuma area (Fig. 14). We suggest that, as with the Parker dunes to the north, a more likely source for these sands is the Colorado River. As discussed earlier, a large eolian sand sheet occurs in the basin occupied by Dale Lake (Tchakerian, 1991; Lancaster and Tchakerian, 1996), in the Mojave Desert of California (Figs. 1, 2, and 15). Because this sand sheet and its coppice dunes are not situated downwind of a major drainage such as the Colorado River, we hypothesize that it is probably derived from local alluvium. This alluvium is in turn eroded from local granitic and metamorphic rocks of the surrounding Sheep Hole Mountains and Pinto Mountains (Fig. 15). 


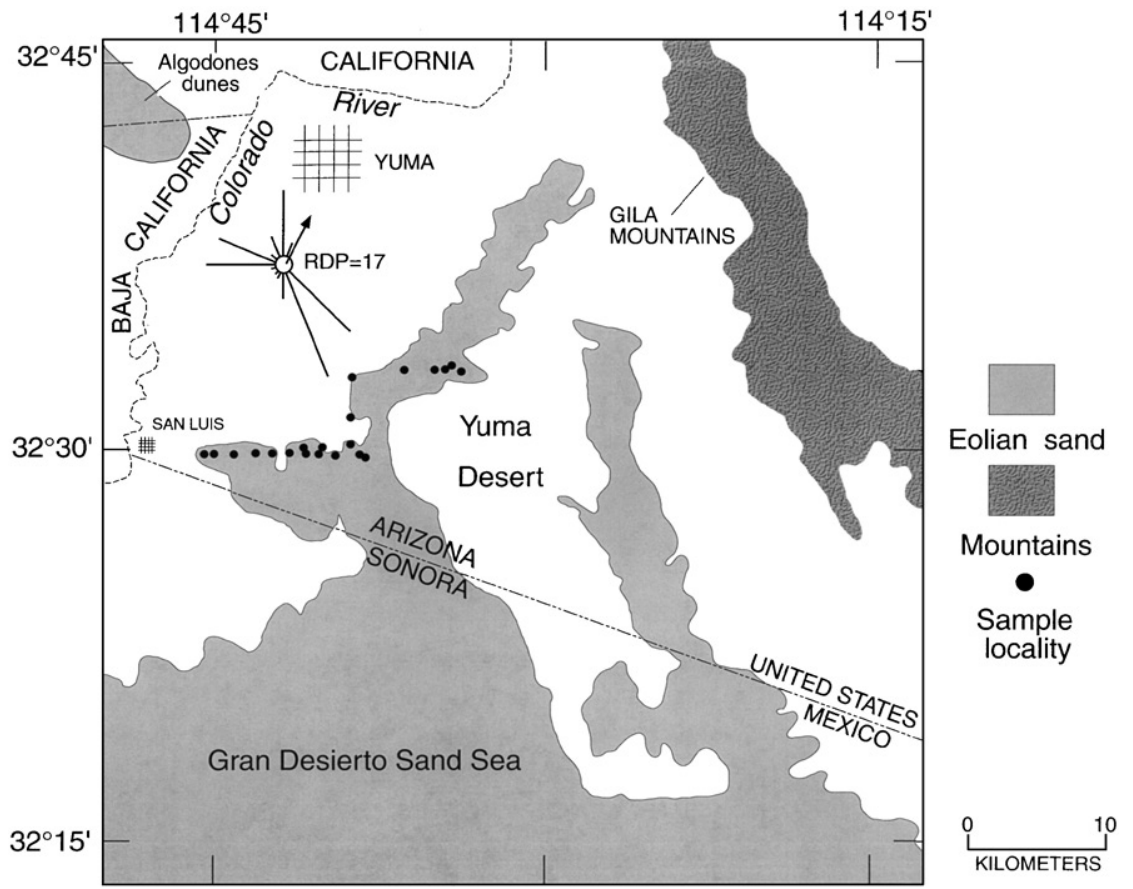

Fig. 14. Distribution of eolian sand in the Yuma Desert area of southern Arizona and the northern part of the Gran Desierto sand sea, Sonora, Mexico, and sample localities. Eolian sand distribution from Olmsted et al. (1973), Direccion General de Geografia (1983), and Lancaster (1995a), with minor modifications based on field work by the authors. Sand rose for Yuma, Arizona calculated by the authors using 1948-1995 climate data.

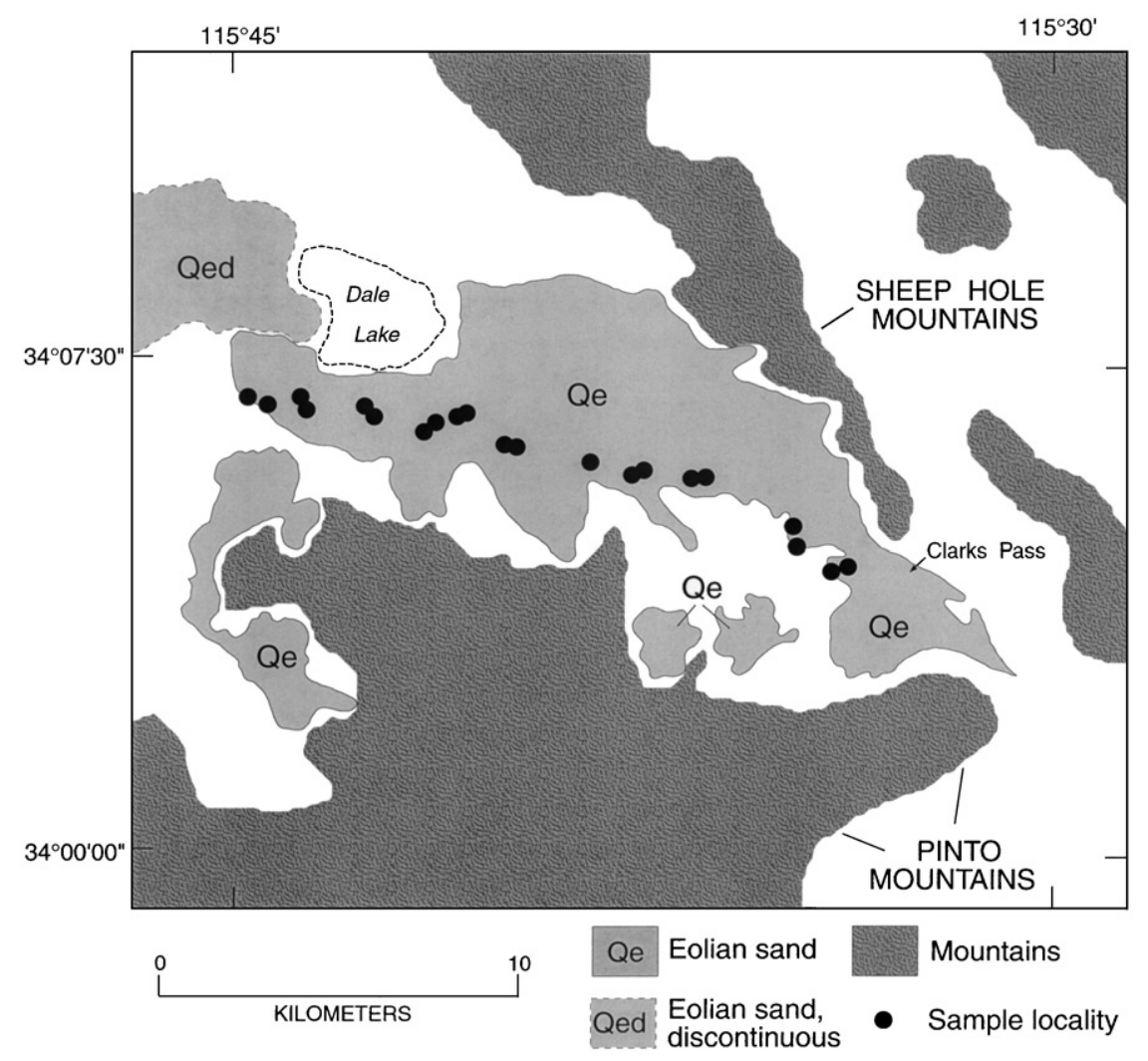

Fig. 15. Distribution of eolian sand in the Dale Lake sand sheet (slightly modified from Bishop, 1963) and sample localities. 

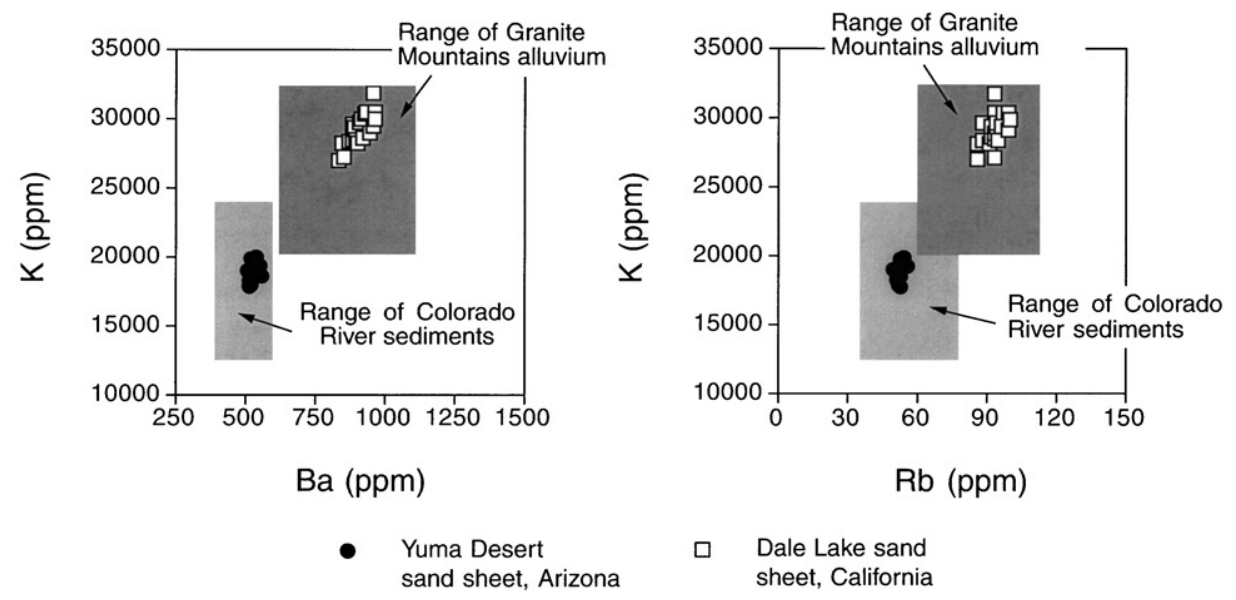

Fig. 16. Plots showing the concentrations of $\mathrm{K}, \mathrm{Ba}$ and $\mathrm{Rb}$ in sediments from coppice dunes and eolian sheet sands of the Yuma Desert and Dale Lake sand sheet. Also shown are the ranges of values for these elements from Colorado River sediments and alluvium derived from the granitic and metamorphic rocks of the Granite Mountains, $\sim 60 \mathrm{~km}$ north of Dale Lake, but with a lithology similar to the Sheep Hole and Pinto Mountains.

Geochemical analyses provide tests of the hypothesized origins of the Yuma Desert and Dale Lake dunes and sand sheets. Yuma Desert sands have low concentrations of $\mathrm{K}, \mathrm{Ba}$, and $\mathrm{Rb}$, which we interpret as low concentrations of K-feldspar (Fig. 16). Concentrations of these elements in the Yuma Desert sands fall within the field of values for Colorado River sediments. In contrast, the Dale Lake eolian sands have higher concentrations of $\mathrm{K}, \mathrm{Ba}$, and $\mathrm{Rb}$ that fall within the field of values for alluvium (500-53 $\mu \mathrm{m}$ fraction) derived from the Granite Mountains. The Granite Mountains are situated in the Mojave Desert $\sim 60 \mathrm{~km}$ north of Dale Lake and are composed of Paleozoic and Mesozoic granitic and metamorphic rocks similar to those in the Sheep Hole and Pinto Mountains. Thus, we interpret the Dale Lake eolian sands to have relatively high Kfeldspar abundances, similar to alluvium derived from nearby granitic mountain ranges.

Wilson (1973), Fryberger and Ahlbrandt (1979), Pye and Tsoar (1990, pp. 127-130), and Cooke et al. (1993, pp. 406-407) suggest that fluvial systems are important sources of sediment for dunes in many of the world's sand seas. However, few empirical data actually exist to link specific riverine sources with dune fields. The results reported here and in previous studies show the importance of the Colorado River in the formation of at least three major dune fields (Parker dunes, Algodones dunes, and Gran Desierto-Yuma Desert dunes) of the southwestern United States and northwestern Mexico. These findings demonstrate the potential significance of large fluvial systems to the origin of desert dune fields. On the other hand, other dune fields (Danby and Dale Lake) likely have their origins in much more locally derived alluvium from nearby mountain ranges.

Derivation of the Parker dunes and Yuma Desert dunes and sand sheets from a Colorado River source may also explain, in part, why these eolian sands are not presently more active. Given the overall moisture deficit in the region, dune mobility index values of $>200$ for nearby Needles and Blythe (Bach, 1995) suggest that the Parker dunes and Yuma Desert eolian sands should be fully active (Lancaster, 1988; Bach, 1995; Muhs et al., 1995). However, historic changes in vegetation cover on the Colorado River floodplain may have diminished the availability of sand to the Parker dune field. Most of the Colorado River floodplain is irrigated and cultivated, resulting in little sediment exposure to eolian entrainment. In addition, islands, bars, and beaches of the modern Colorado River channel have increasingly been stabilized by the spread of tamarisk since the mid-1800s (Graf, 1978). Thus, as with the dunes of the Southern High Plains of New Mexico and Texas (Muhs and Holliday, 2001), the Parker dunes may at present have a sediment supply, but low sediment availability (Kocurek and Lancaster, 1999).

Despite the lack of available new sediment from the Colorado River, the sand that already exists in the Parker dune field should be more active than it is, based on the Lancaster (1988) dune mobility index. The Algodones dunes, which also have a low sediment availability (based on identification of the source sediments), are fully active at present and are predicted to be fully active, based on the mobility index (Muhs et al., 1995). The Lancaster dune mobility index uses the percentage of time that wind is above the threshold velocity, $W$, as one of its factors. However, this parameter does not consider wind direction variability, only the sum of winds from any direction above the threshold velocity. Thus, if equally strong, seasonal winds from opposing directions dominated a region, $W$ in the dune mobility index could be very high but the net sand movement over a period of a year may be zero. Linear dunes, such as those in the Parker dune field, 
Blythe, California

Winter winds

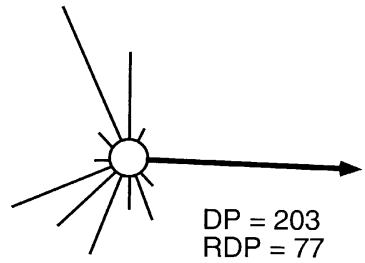

Spring/summer winds
"Drop One," Algodones

dunes, California

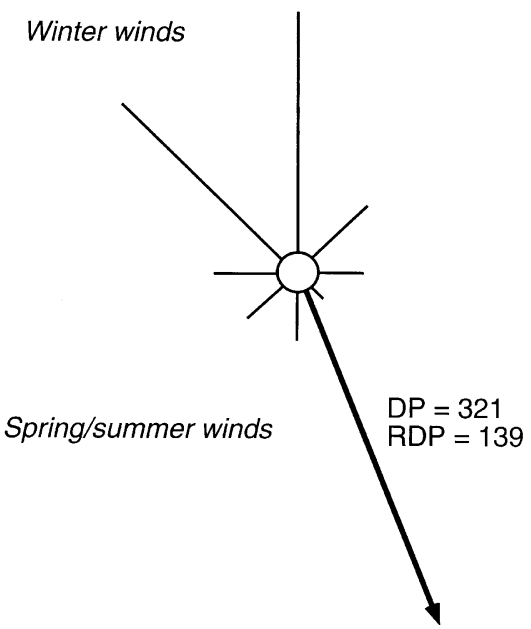

Fig. 17. Annual sand rose diagrams for Blythe, California, near the Parker dunes (data from Muhs et al., 1995) and "Drop One" in the Algodones dune field (data from Havholm and Kocurek, 1988). DP is drift potential; RDP is resultant drift potential.

often occur in climatic regimes characterized by seasonally variable winds (Fryberger and Dean, 1979; Lancaster, 1995b). Tsoar and Illenberger (1998) used the concept of wind direction variability as a factor in dune mobility to challenge the use of the Lancaster (1988) mobility index. Examination of the wind regimes around the Parker and Algodones dunes allows a test of this hypothesis. The closest weather station to the Parker dunes with wind data is Blythe, California and wind data exist for a locality called "Drop One" in the Algodones dune field. At Drop One in the Algodones, winter winds come from the north and northwest and are relatively strong; southwesterly summer winds are relatively weak (Fig. 17). Resultant drift potential (RDP) is, therefore, relatively strong (139) and is northwest-to-southeast, consistent with dune orientations (Muhs et al., 1995). In contrast, at Blythe, winter winds from the north and northwest and summer winds from the southwest are about equal in strength; overall drift potential (DP) is lower than at Drop One, and RDP is almost a factor of two lower. Thus, the possibility exists that because of the higher RDP in the Algodones dune field, the overall degree of dune activity is higher. This explanation needs more testing, but is presented here as a working hypothesis that may refine the Lancaster (1988) dune mobility index.

\section{Summary and conclusions}

Based on studies of dune fields and possible source sediments in the Mojave Desert of California and the
Sonoran Desert of western Arizona, we conclude the following:

(1) The Parker dunes consist of northeast-trending linear dunes, with smaller areas of northeasttrending parabolic dunes, coppice dunes, and eolian sheet sands. Dune-forming winds came from the southwest. Stratigraphic data indicate that the dune field had at least three cycles of eolian sedimentation in the late Quaternary, as evidenced by two buried soils with well-developed stage II calcic horizons, similar to the stratigraphy of dune fields in the eastern Mojave Desert of California.

(2) The Parker dunes are quartz-rich, with lesser amounts of K-feldspar, plagioclase and calcite, consistent with geochemical data indicating relatively low concentrations of $\mathrm{K}, \mathrm{Ba}, \mathrm{Ca}$ and $\mathrm{Sr}$.

(3) Mineralogical, geochemical, and magnetic data all show that the Parker dunes more closely resemble the composition of Colorado River sediments than dunes of the eastern Mojave Desert or a local source, Bouse Wash. Similarity of quartz-rich dunes on both sides of Bouse Wash suggest that dunes regularly crossed this dry valley, but the drainage itself probably contributed little sediment.

(4) Eolian sands of the Parker dune field and the Yuma Desert probably originated from the Colorado River valley, rather than from local sources or by transport across the Colorado River from the eastern Mojave Desert. The Colorado River is actually a barrier to eastward eolian sediment transport from the Mojave Desert. Eolian sands in the eastern Mojave Desert of California (the 
Danby dunes and the Dale Lake sand sheet) are probably derived from local, K-feldspar-rich alluvium derived from nearby granitic mountain ranges.

(5) Stabilization of channel and floodplain sediments by tamarisk (channel) and cultivated crops (floodplain) may have resulted in little new sediment availability to the Parker dunes and Yuma Desert in historic time. However, this mechanism does not explain the fully active Algodones dunes, which also have low sediment availability, but unlike the Parker dunes, are fully active. Greater variability of wind directions in the Parker area (in addition to lower wind strength overall) may contribute to dune stability, but this hypothesis needs more testing.

(6) The Colorado River appears to have been an important sediment source for at least three of the major dune fields of the Sonoran Desert of the southwestern United States and northwestern Mexico. On the other hand, locally derived alluvium is important as a source for several dune fields of the Mojave Desert of California. These findings support the theory, presently without much empirical evidence, that major fluvial systems are important in the origin of some desert dune fields, but that local sources are more important for others.

\section{Acknowledgements}

This study was supported by the Earth Surface Dynamics Program of the US Geological Survey and is a contribution to the "Climate Impacts on Southwestern US Landscapes" and "Eolian History of North America" projects. Zachary Muhs Rowland assisted with sediment sampling during three field seasons and Laura Strickland identified the dune and interdune plants. Brian Marshall assisted with geochemical analyses. We thank Jim Zimbelman, Steve Williams, Patrick Pease and Vatche Tchakerian, who conducted parallel studies, for helpful discussions. Nick Lancaster, Steve Wolfe, Patrick Pease, Marith Reheis and Gary Clow made constructive comments on an earlier draft of the paper, which we appreciate.

\section{References}

Arbogast, A.F., Muhs, D.R., 2000. Geochemical and mineralogical evidence from eolian sediments for northwesterly mid-Holocene paleowinds, central Kansas, USA. Quaternary International 67, 107-118.

Bach, A.J., 1995. Climatic controls on aeolian activity in the Mojave and Colorado Deserts, California. Unpublished Ph.D. thesis, Arizona State University, 308 pp.
Billingsley, G.H., 1987. Geology and geomorphology of the southwestern Moenkopi Plateau and southern Ward Terrace, Arizona. United States Geological Survey Bulletin 1672, 18 pp.

Bishop, C.C., 1963. Geologic Map of California-Needles Sheet. California Division of Mines and Geology, scale 1:250,000.

Blount, G., Lancaster, N., 1990. Development of the Gran Desierto sand sea, northwestern Mexico. Geology 18, 724-728.

Breed, C.S., 1999. Monitoring surface changes in desert areas. United States Geological Survey Professional Paper 1598-A, 1-27.

Breed, C.S., Fryberger, S.C., Andrews, S., McCauley, C., Lennartz, F., Gebel, D., Horstman, K., 1979. Regional studies of sand seas using Landsat (ERTS) imagery. In: McKee, E.D. (Ed.), A Study of Global Sand Seas. United States Geological Survey Professional Paper, Washington D.C 1052, 305-397.

Clarke, M.L., 1994. Infra-red stimulated luminescence ages from aeolian sand and alluvial fan deposits from the eastern Mojave Desert, California. Quaternary Science Reviews (Quaternary Geochronology) 13, 533-538.

Clarke, M.L., Rendell, H.M., 1998. Climate change impacts on sand supply and the formation of desert sand dunes in the south-west U.S.A. Journal of Arid Environments 39, 517-531.

Clarke, M.L., Wintle, A.G., Lancaster, N., 1996. Infra-red stimulated luminescence dating of sands from the Cronese Basins, Mojave Desert. Geomorphology 17, 199-205.

Cooke, R., Warren, A., Goudie, A., 1993. Desert Geomorphology. UCL Press Limited, London, 526pp.

Direccion General de Geografia, 1983. Carta geologica (Mexicali sheet). Coordinacion General de los Servicios Nacionales de Estadistica, Geografia e Informatica, Mexico City, Mexico, scale 1:250,000.

Dutta, P.K., Zhou, Z., dos Santos, P.R., 1993. A theoretical study of mineralogical maturation of eolian sand. Geological Society of America Special Paper 284, 203-209.

Fryberger, S.G., Ahlbrandt, T.S., 1979. Mechanisms for the formation of eolian sand seas. Zeitschrift für Geomorphologie 23, 440-460.

Fryberger, S.G., Dean, G., 1979. Dune forms and wind regime. In: McKee, E.D. (Ed.), A Study of Global Sand Seas. United States Geological Survey Professional Paper, Washington D.C 1052, 137-169.

Gile, L.H., Hawley, J.W., Grossman, R.B., 1981. Soils and geomorphology in the Basin and Range area of southern New MexicoGuidebook to the Desert Project. New Mexico Bureau of Mines and Mineral Resources Memoir 39, 222 pp.

Graf, W.L., 1978. Fluvial adjustments to the spread of tamarisk in the Colorado Plateau region. Geological Society of America Bulletin 89, 1491-1501.

Grove, A.T., Warren, A., 1968. Quaternary landforms and climate on the south side of the Sahara. Geographical Journal 134, 194-208.

Hack, J.T., 1941. Dunes of the western Navajo Country. Geographical Review 31, 240-263.

Havholm, K.G., Kocurek, G., 1988. A preliminary study of the dynamics of a modern draa, Algodones, southeastern California, USA. Sedimentology 35, 649-669.

Haynes, C.V., 1980. Geochronology of Wadi Tushka: lost tributary of the Nile. Science 210, 68-71.

Helm, P.J., Breed, C.S., 1999. Instrumented field studies of sediment transport by wind. United States Geological Survey Professional Paper 1598-B, 29-51.

Holliday, V.T., 1995. Stratigraphy and paleoenvironments of late Quaternary valley fills on the Southern High Plains. Geological Society of America Memoir 186, 136 pp.

Howard, C.S., 1947. Suspended sediment in the Colorado River, 1925-41 United States Geological Survey Water-Supply Paper 998, 165 pp.

Jennings, C.W., 1967. Geologic Map of California, Salton Sea Sheet. California Division of Mines and Geology, scale 1:250,000. 
Kocurek, G., Lancaster, N., 1999. Aeolian system sediment state: theory and Mojave Desert Kelso dune field example. Sedimentology 46, 505-515.

Kuenen, Ph.H., 1960. Experimental abrasion 4: Eolian action. Journal of Geology 68, 427-449.

Lancaster, N., 1988. Development of linear dunes in the southwestern Kalahari, southern Africa. Journal of Arid Environments 14, 233-244.

Lancaster, N., 1994. Controls on aeolian activity: some new perspectives from the Kelso Dunes, Mojave Desert, California. Journal of Arid Environments 27, 113-125.

Lancaster, N., 1995a. Origin of the Gran Desierto sand sea, Sonora, Mexico: Evidence from dune morphology and sedimentology. In: Tchakerian, V.P. (Ed.), Desert Aeolian Processes. Chapman and Hall, London, pp. 11-35.

Lancaster, N., 1995b. Geomorphology of Desert Dunes. Routledge, London, $290 \mathrm{pp}$.

Lancaster, N., Tchakerian, V.P., 1996. Geomorphology and sediments of sand ramps in the Mojave Desert. Geomorphology 17, 151-165.

Lancaster, N., Greeley, R., Christensen, P.R., 1987. Dunes of the Gran Desierto sand-sea, Sonora, Mexico. Earth Surface Processes and Landforms 12, 277-288.

Loope, D.B., Swinehart, J.B., Mason, J.P., 1995. Dune-dammed paleovalleys of the Nebraska Sand Hills: intrinsic versus climatic controls on the accumulation of lake and marsh sediments. Geological Society of America Bulletin 107, 396-406.

Machette, M.N., 1985. Calcic soils of the southwestern United States. Geological Society of America Special Paper 203, 1-21.

Mainguet, M., Cossus, L., Chapelle, A.M., 1980. Utilisation des images Metéosat pour préciser les trajectoires éoliennes au sol, au Sahara et sur les marges Saheliennes. Société Française de Photogrammetrie et de Télédétection 78, 1-14.

Marsland, P.S., Woodruff, J.G., 1937. A study of the effects of wind transportation on grains of several minerals. Journal of Sedimentary Petrology 7, 18-30.

Mason, B., Moore, C.B., 1982. Principles of Geochemistry. Wiley, New York, 344pp.

Mason, J.P., Swinehart, J.B., Loope, D.B., 1997. Holocene history of lacustrine and marsh sediments in a dune-blocked drainage, southwestern Nebraska Sand Hills, U.S.A. Journal of Paleolimnology 17, 67-83.

Metzger, D.G., Loeltz, O.J., Irelna, B., 1973. Geohydrology of the Parker-Blythe-Cibola area, Arizona and California. United States Geological Survey Professional Paper 486-C, 130 pp.

Muhs, D.R., Holliday, V.T., 1995. Evidence for active dune sand on the Great Plains in the 19th century from accounts of early explorers. Quaternary Research 43, 198-208.

Muhs, D.R., Holliday, V.T., 2001. Origin of late Quaternary dune fields on the Southern High Plains of Texas and New Mexico. Geological Society of America Bulletin 113, 75-87.

Muhs, D.R., Maat, P.B., 1993. The potential response of eolian sands to greenhouse warming and precipitation reduction on the Great Plains of the U.S.A. Journal of Arid Environments 25, 351-361.

Muhs, D.R., Zárate, M., 2001. Late Quaternary eolian records of the Americas and their paleoclimatic significance. In: Markgraf, V. (Ed.), Interhemispheric Climate Linkages. Academic Press, San Diego, pp. 183-216.

Muhs, D.R., Bush, C.A., Cowherd, S.D., Mahan, S., 1995. Geomorphic and geochemical evidence for the source of sand in the Algodones dunes, Colorado Desert, southeastern California. In: Tchakerian, V.P. (Ed.), Desert Aeolian Processes. Chapman and Hall, London, pp. 37-74.

Muhs, D.R., Stafford, T.W. Jr., Cowherd, S.D., Mahan, S.A., Kihl, R., Maat, P.B., Bush, C.A., Nehring, J., 1996. Origin of the late Quaternary dune fields of northeastern Colorado. Geomorphology $17,129-149$.
Muhs, D.R., Stafford, T.W. Jr., Swinehart, J.B., Cowherd, S.D., Mahan, S.A., Bush, C.A., Madole, R.F., Maat, P.B., 1997a. Late Holocene eolian activity in the mineralogically mature Nebraska Sand Hills. Quaternary Research 48, 162-176.

Muhs, D.R., Stafford, T.W. Jr., Been, J., Mahan, S., Burdett, J., Skipp, G., Rowland, Z.M., 1997b. Holocene eolian activity in the Minot dune field, North Dakota. Canadian Journal of Earth Sciences 34, 1442-1459.

Muhs, D.R., Swinehart, J.B., Loope, D.B., Been, J., Mahan, S.A., Bush, C.A., 2000. Geochemical evidence for an eolian sand dam across the North and South Platte Rivers in Nebraska. Quaternary Research 53, 214-222 pp.

Olmsted, F.H., Loeltz, O.J., Irelan, B., 1973. Geohydrology of the Yuma area, Arizona and California. United States Geological Survey Professional Paper 486-H, 227.

Pease, P., Tchakerian, V., 2002. Geochemistry of sediments from Quaternary sand ramps in the southeastern Mojave Desert, California. Quaternary International, this issue.

Pye, K., Tsoar, H., 1990. Aeolian Sand and Sand Dunes. Unwin Hyman, London, 396 pp.

Rendell, H.M., Sheffer, N.L., 1996. Luminescence dating of sand ramps in the Eastern Mojave Desert. Geomorphology 17, 187-197.

Rendell, H.M., Lancaster, N., Tchakerian, V.P., 1994. Luminescence dating of late Quaternary aeolian deposits at Dale Lake and Cronese Mountains, Mojave Desert, California. Quaternary Science Reviews (Quaternary Geochronology) 13, 417-422.

Rosenbaum, J.G., Reynolds, R.L., Adam, D.P., Drexler, J., Sarna-Wojcicki, A.M., Whitney, G.C., 1996. Record of middle Pleistocene climate change from Buck Lake, Cascade Range, southern Oregon-Evidence from sediment magnetism, traceelement geochemistry, and pollen. Geological Society of America Bulletin 108, 1328-1341.

Tchakerian, V.P., 1991. Late Quaternary aeolian geomorphology of the Dale Lake sand sheet, southern Mojave Desert, California. Physical Geography 2, 347-369.

Tchakerian, V.P., Lancaster, N., 2002. Late Quaternary arid/humid cycles in the Mojave Desert and western Great Basin of North America. Quaternary Science Reviews 21, 799-810.

Teller, J.T., Lancaster, N., 1986. Lacustrine sediments at Narabeb in the central Namib Desert, Namibia. Palaeogeography, Palaeoclimatology, Palaeoecology 56, 177-195.

Tosdal, R.M., Eppinger, R.G., Erdman, J.A., Hanna, W.F., Pitkin, J.A., Blank, H.R. Jr., O'Leary, R.M., Watterson, J.R., 1990. Mineral resources of the Cactus Plain and East Cactus Plain Wilderness study areas, La Paz County, Arizona. United States Geological Survey Bulletin 1704, 32 pp.

Tsoar, H., Illenberger, W., 1998. Reevaluation of sand dunes' mobility indices. Journal of Arid Land Studies 7S, 265-268.

Wells, S.G., McFadden, L.D., Schultz, J.D., 1990. Eolian landscape evolution and soil formation in the Chaco dune field, southern Colorado Plateau, New Mexico. Geomorphology 3, 517-546.

Wilson, I.G., 1973. Ergs. Sedimentary Geology 10, 77-106.

Winspear, N.R., Pye, K., 1995. Sand supply to the Algodones dunefield, south-eastern California, USA. Sedimentology 42, 875891.

Wintle, A.G., Lancaster, N., Edwards, S.R., 1994. Infrared stimulated luminescence dating of late-Holocene aeolian sands in the Mojave Desert, California, USA. The Holocene 4, 74-78.

Zimbelman, J.R., Williams, S.H., 2002. Geochemical indicators of separate sources for eolian sands in the eastern Mojave Desert, California, and western Arizona. Geological Society of America Bulletin 114, 490-496.

Zimbelman, J.R., Williams, S.H., Tchakerian, V.P., 1995. Sand transport paths in the Mojave Desert, southwestern United States. In: Tchakerian, V.P. (Ed.), Desert Aeolian Processes. Chapman and Hall, London, pp. 101-129. 